\title{
Aplikasi Edukasi Biologi Tentang Sistem Reproduksi Manusia Berbasis Flash CS3 di SMP Buddhi Tangerang
}

\author{
Ardhie Halim Wijaya \\ STMIK BUDDHI \\ Jl. Imam Bonjol No. 41, Tangerang Banten Indonesia \\ ardhie.h@gmail.com
}

\begin{abstract}
SMP Buddhi sebagai salah satu sekolah menengah yang sedang berkembang dengan bentuk dan struktur yang baru, memerlukan banyak dukungan termasuk juga dukungan teknologi Informasi dalam mencapai sasaran yang baru. Sistem dan cara pembelajaran yang lebih modern dan interaktif dapat menunjang tercapainya suasana belajar yang nyaman dan tidak membuat siswa menjadi bosan dalam kegiatan belajar di sekolah. Pengambilan judul ini dilatar belakangi dikarenakan Pendidikan merupakan suatu hal yang sangat penting bagi setiap manusia, karena dengan pendidikan, manusia tersebut akan lebih mudah membangun dan menuntun hidupnya ke arah yang lebih baik lagi. Bagian dari pendidikan yang paling umum yaitu salah satunya adalah pendidikan biologi. Namun salah satu masalah umum yang timbul dalam bidang pendidikan biologi dalam proses pembelajaran adalah masalah verbalisme, yaitu anak dapat menghafal dan mengucapkan kata-kata tetapi tidak dapat memahami maksud atau artinya. Karena banyak dari pengajar dalam penyampaian bahan pengajaran hanya menggunakan bahasa lisan atau tulisan tanpa disertai alat pendukung yang lebih konkrit yang dapat memperjelas materi yang disampaikan oleh pengajar. Metode perancangan system yang digunakan dalam penulisan ini adalah perancangan storyboard dan perancangan user interface. Hasil yang ingin dicapai oleh penulis dalam skripsi ini adalah terciptanya sebuah program aplikasi yang dapat menambah wawasan dan memudahkan para siswa dalam pelajaran biologi khususnya sistem reproduksi manusia, terciptanya program yang menarik dan cukup mudah untuk digunakan. Kesimpulan dari penulisan skripsi ini adalah bahwa program aplikasi edukasi ini menggunakan bahasa pemrograman Flash CS3 dan selain menampilkan materi pelajaran juga menampilkan uji kompetensi siswa menambah wawasan siswa, dan aplikasi ini ditujukan kepada siswa SMP kelas IX.
\end{abstract}

Kata Kunci: Perancangan, Aplikasi, Edukasi, Biologi, Flash CS3.

\section{PENDAHULUAN}

Pendidikan merupakan suatu hal yang sangat penting bagi setiap manusia, karena dengan pendidikan, manusia tersebut akan lebih mudah membangun dan menuntun hidupnya ke arah yang lebih baik lagi. Bagian dari pendidikan yang paling umum yaitu salah satunya adalah pendidikan biologi.

Pendidikan biologi sangat penting dilihat dari berbagai aspek pendidikan. Biologi sebagai bagian dari

\author{
Fanny Fransisca \\ STMIK BUDDHI \\ Jl. Imam Bonjol No. 41, Tangerang Banten Indonesia \\ stelovfan@ymail.com
}

mata pelajaran sains sangat berkaitan dengan cara mencari tahu tentang alam semesta secara sistematis, sehingga diharapkan dapat menjadi wahana bagi siswa untuk mempelajari diri sendiri dan alam sekitarnya. Namun salah satu masalah umum yang timbul dalam bidang pendidikan biologi dalam proses pembelajaran adalah masalah verbalisme, yaitu anak dapat menghafal dan mengucapkan kata-kata tetapi tidak dapat memahami maksud atau artinya. Karena banyak dari pengajar dalam penyampaian bahan pengajaran hanya menggunakan bahasa lisan atau tulisan tanpa disertai alat pendukung yang lebih konkrit yang dapat memperjelas materi yang disampaikan oleh pengajar.

\section{METODOLOGI PENELITIAN}

\section{A. Analisa Penelitian}

1) Planning

Pada tahap ini, memahami permasalahan yang muncul dan mendefinisikan secara rinci, kemudian menentukan tujuan pembuatan sistem dan mengidentifikasi segala kendala yang akan dihadapi.

Adapun tahapan - tahapannya, yaitu :

- Menyadari permasalahan

- Mendefinisikan permasalahan

- Menentukan tujuan sistem

- Mengidentifikasi kendala sistem

- Membuat studi kelayakan

- Menyiapkan usulan penelitian sistem

- Menetapkan mekanisme pengendalian

2) Analisis

Setelah melakukan perencanaan dan mekanisme pengendalian yang diterapkan, selanjutnya adalah menganalisa sistem yang berjalan dengan tahapan sebagai berikut :

- Mendefinisikan kebutuhan informasi.

- Mendefinisikan kriteria performansi sistem.

3) Desain 
Menentukan kebutuhan proses dan data pada sistem baru yang akan dirancang, langkah langkahnya sebagai berikut:

- Menyiapkan rancangan sistem secara detil.

- Mengidentifikasi alternatif konfigurasi sistem.

- Mengevaluasi alternatif konfigurasi sistem.

4) Implementasi

Merupakan suatu kegiatan dalam mengimplementasikan rancangan yang telah disusun agar dapat diwujudkan, dengan langkah langkah sebagai berikut :

- Merencanakan implementasi.

- Memberitahukan adanya implementasi.

- Menyediakan resource hardware dan software.

- Menyiapkan database.

- Menyiapkan berbagai fasilitas fisik.

- Pelatihan para partisipan dan user.

B. Metode Pengumpulan Data

1) Studi Kepustakaan

Pengumpulan data dan informasi yang diperlukan untuk digunakan dalam pembuatan aplikasi ini.

2) Metode Kuisioner

Dalam penelitian ini metode yang digunakan untuk memperoleh informasi dari responden adalah kuisioner. Jenis kuisioner ini adalah adalah kuisioner tertutup yang disediakan jawabannya sehingga responden hanya perlu memilih jawaban pada kolom yang sudah disediakan dengan memberikan tanda centang $(\sqrt{ })$.

\section{PERANCANGAN SISTEM}

\section{A. Analisa Kebutuhan Sistem}

Untuk memenuhi kebutuhan pengguna maka peneliti perlu mengadakan survey kepada beberapa orang yang paham dalam pembuatan aplikasi pembelajaran dan atau yang paham tentang system reproduksi manusia. Dimana jawaban responden merupakan pernyataan apa saja yang diperlukan dalam pembuatan aplikasi yang dibuat oleh peneliti.

Berdasarkan hasil survey yang telah dilakukan kepada 20 responden yang mengerti tentang aplikasi edukasi, maka didapatkan beberapa pernyataan yang mungkin dapat diterapkan dalam aplikasi edukasi biologi tentang sistem reproduksi manusia ini. Adapun uraian tersebut yaitu:

Tabel 1. Tabel Analisa Kebutuhan Pemakai

\begin{tabular}{|c|l|}
\hline No. & \multicolumn{1}{|c|}{ Kebutuhan Pemakai } \\
\hline 1 & $\begin{array}{l}\text { Terdapat informasi mengenai cara menggunakan } \\
\text { aplikasi }\end{array}$ \\
\hline 2 & Memiliki tampilan yang menarik \\
\hline 3 & Materi pada aplikasi ini mudah dipahami siswa \\
\hline 4 & $\begin{array}{l}\text { Materi yang ditampilkan mengacu pada } \\
\text { kurikulum yang berlaku }\end{array}$ \\
\hline
\end{tabular}

\begin{tabular}{|c|l|}
\hline 5 & $\begin{array}{l}\text { Terdapat lembar kerja siswa mengenai materi } \\
\text { yang berkaitan }\end{array}$ \\
\hline 6 & Soal berupa pilihan ganda \\
\hline 7 & Soal yang ditampilkan acak atau random \\
\hline 8 & Memiliki informasi materi yang lengkap \\
\hline 9 & Menyediakan layanan edukasi \\
\hline 10 & Memiliki efek suara yang menarik \\
\hline 11 & Aplikasi yang dibuat dapat mendidik siswa \\
\hline 12 & Edukasi yang diberikan, ada atau disertai gambar \\
\hline 13 & Dapat menambah semangat siswa dalam belajar \\
\hline 14 & Aplikasi yang dibuat dapat bermanfaat \\
\hline 15 & $\begin{array}{l}\text { Menampilkan skor atau nilai setelah permainan } \\
\text { selesai }\end{array}$ \\
\hline
\end{tabular}

\section{B. Perancangan User Interface}

Perancangan dari sistem berdasarkan tema penelitian ini menghasilkan beberapa halaman yang serupa dengan berisikan materi yang berbeda antara satu pembahasan dengan pembahasan lainnya. Adapun tampilan - tampilan program adalah sebagai berikut:

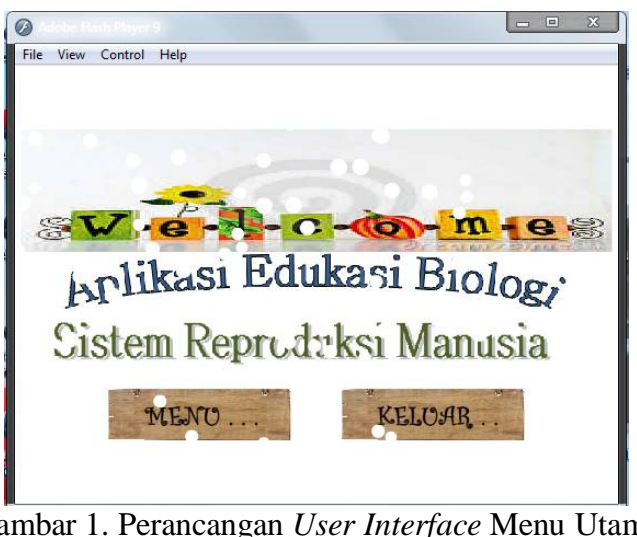

Rancangan menu utama ini merupakan halaman utama dalam aplikasi edukasi biologi yang berisikan menu-menu yang terhubung ke halaman-halaman lainnya. Halaman ini memiliki dua tombol yang terletak di bawah gambar serta musik pengiring. Tombol menu digunakan untuk memilih materi dalam aplikasi ini. User dapat mengklik tombol ini jika user ingin mulai menjalankan aplikasi edukasi biologi. 


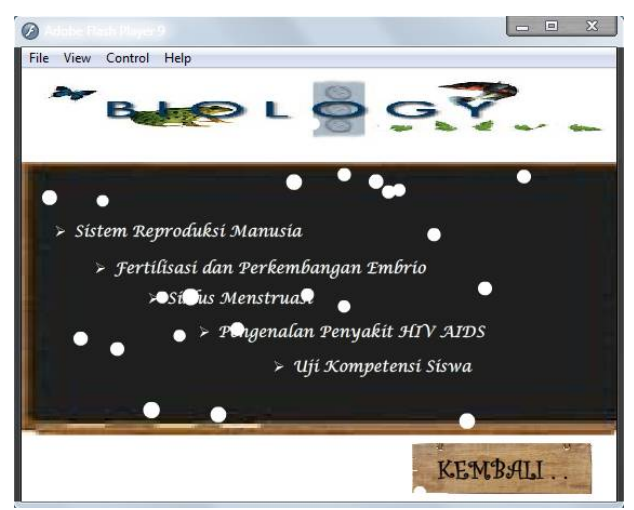

Gambar 2. Perancangan User Interface Menu Pilihan

Rancangan menu pilihan aplikasi ini merupakan halaman dalam aplikasi edukasi yang berisikan enam tombol yaitu tombol Sistem Reproduksi Manusia, Fertilisasi \& perkembangan embrio, siklus menstruasi, mengenal penyakit AIDS, Uji kompetensi siswa, dan tombol kembali. Tombol sistem reproduksi manusia digunakan untuk melihat materi sisterm reprodusi manusia, tombol fertilisasi dan perkembangan embrio digunakan untuk mengetahui materi fertilisasi dan perkembangan embrio, tombol siklus menstruasi digunakan untuk mengetahui materi siklus menstruasi, tombol pengenalan penyakit AIDS berisi mengenai virus dan penularan penyakit AIDS, dan tombol kembali berfungsi untuk kembali kemenu utama.

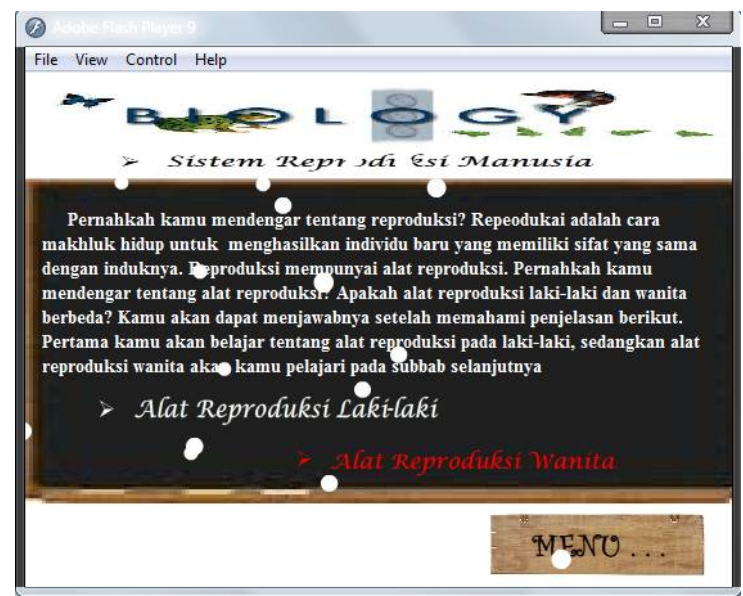

Gambar 3. Perancangan User Interface Sister Reproduksi Manusia

Halaman ini ditampilkan saat pemain mengklik tombol sistem reproduksi manusia. Dalam halaman ini selain menampilkan penjelasan sistem reproduksi terdapat pula 3 tombol yaitu: Tombol alat reproduksi laki - laki tombol ini berfungsi untuk melihat materi tentang alat reproduksi laki - laki, Tombol alat reproduksi wanita tombol ini berfungsi untuk melihat materi tentang alat reproduksi wanita, tombol kembali berfungsi untuk kembali kemenu sebelumnya.

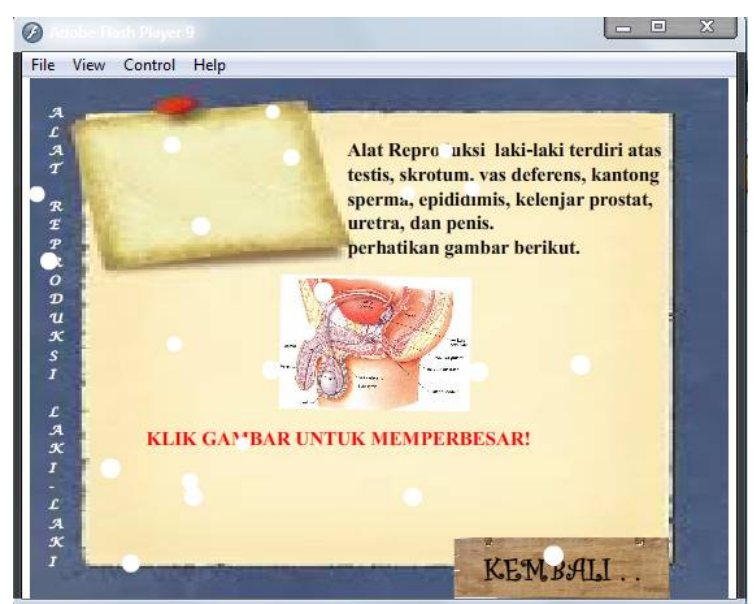

Gambar 4. Perancangan User Interface alat reproduksi laki - laki

Halaman ini ditampilkan saat pemain mengklik tombol alat reproduksi laki - laki pada menu sistem reproduksi manusia. Dalam halaman ini keterangan mengenai materi alat reproduksi laki - laki. Dalam halaman ini terdapat satu tombol yaitu tombol kembali yang berfungsi untuk kembali ke menu sistem reproduksi manusia.

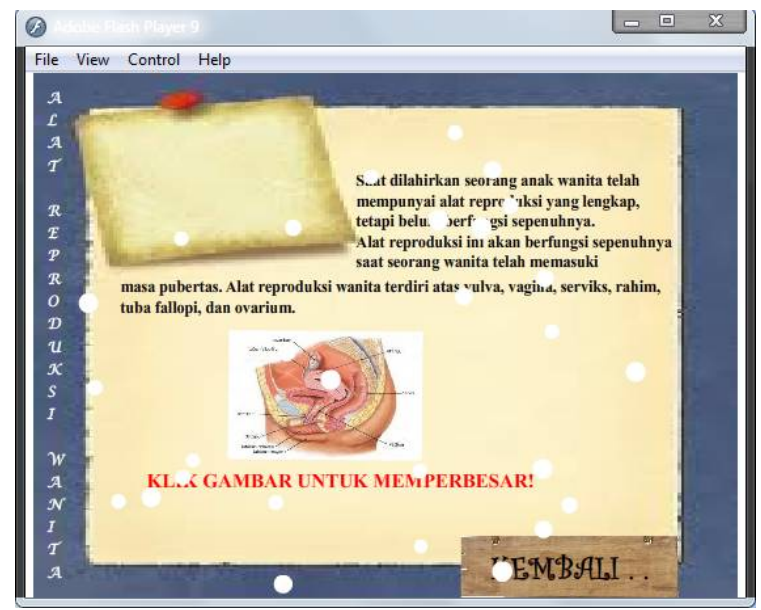

Gambar 5. Perancangan User Interface Alat Reproduksi Wanita

Halaman ini ditampilkan saat pemain mengklik tombol alat reproduksi wanita pada menu sistem reproduksi manusia. Dalam halaman ini keterangan mengenai materi alat reproduksi wanita. Dalam halaman ini terdapat satu tombol yaitu tombol kembali yang berfungsi untuk kembali ke menu sistem reproduksi manusia. 


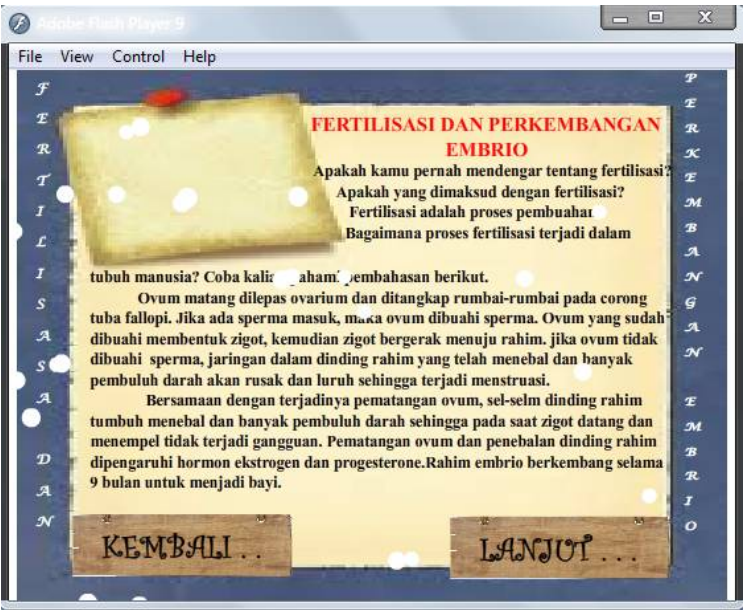

Gambar 6. Perancangan User Interface Fertilisasi dan perkembangan embrio

Halaman ini ditampilkan saat pemain mengklik tombol Fertilisasi dan perkembangan embrio pada menu pilihan. Dalam halaman ini keterangan mengenai materi fertilisasi dan perkembangan embrio. Dalam halaman ini terdapat dua tombol yaitu tombol kembali yang berfungsi untuk kembali ke menu pilihan dan tombol lanjut untuk ke halaman berikutnya.

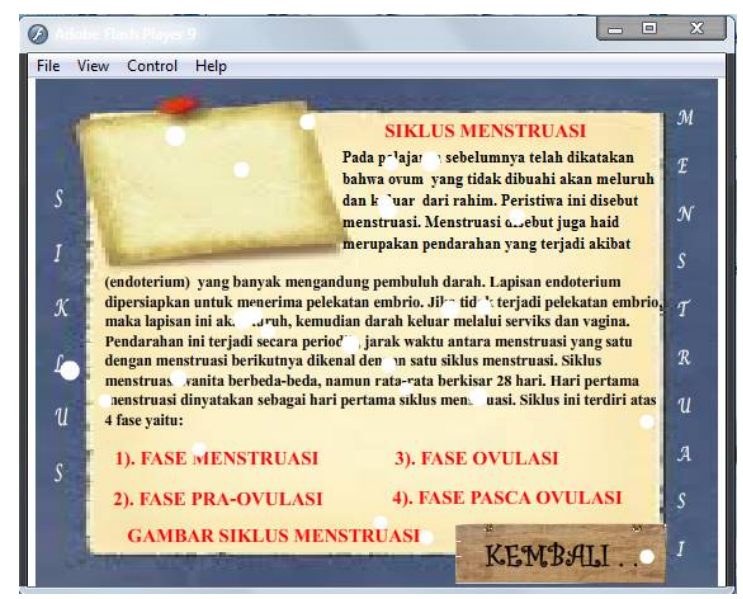

Gambar 7. Perancangan User Interface Siklus Menstruasi

Halaman ini ditampilkan saat pemain mengklik tombol siklus menstruasi pada menu pilihan. Dalam halaman ini keterangan mengenai materi siklus menstruasi. Dalam halaman ini terdapat satu tombol yaitu tombol kembali yang berfungsi untuk kembali ke menu pilihan.

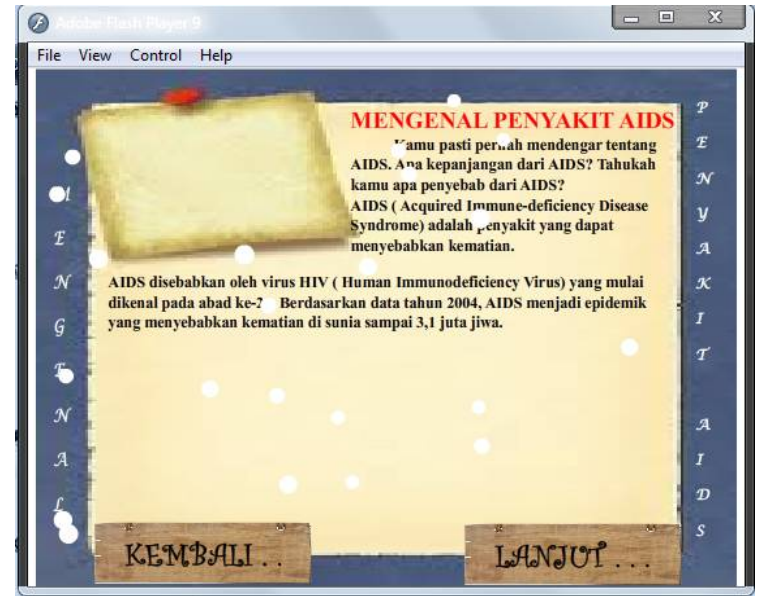

Gambar 8. Perancangan User Interface Mengenal penyakit AIDS

Halaman ini ditampilkan saat pemain mengklik tombol mengenal penyakit AIDS pada menu pilihan. Dalam halaman ini keterangan mengenai materi mengenal penyakit AIDS. Dalam halaman ini terdapat dua tombol yaitu tombol kembali yang berfungsi untuk kembali ke menu pilihan, dan tombol lanjut untuk ke halaman selanjutnya.

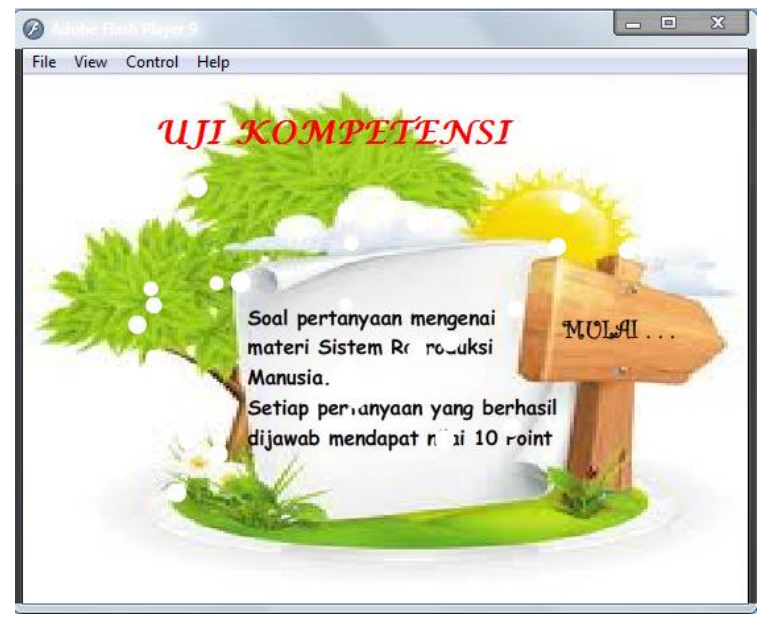

Gambar 9. Perancangan User Interface cara mengerjakan Uji kompetensi siswa

Halaman ini ditampilkan saat pemain mengklik tombol Uji kompetensi siswa. Halaman ini berisi cara mengerjakan soal pada ujinkompetensi siswa. Tombol Mulai berfungsi untuk memulai ngerjakan soal pada halaman uji kompetensi. 


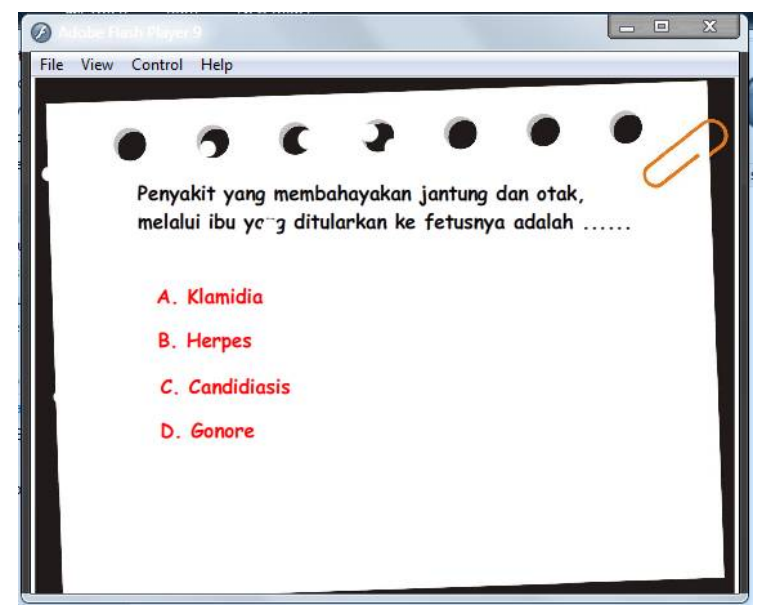

Gambar 10. Perancangan User Interface Uji kompetensi siswa

Halaman ini ditampilkan saat pemain mengklik tombol mulai. Halaman ini berisi nilai, soal dan pilihan jawaban. Di dalam halaman ini berisi satu tombol yaitu tombol Score. Tombol Score berfungsi untuk melihat score dari hasil nilai jawaban yang user jawab.

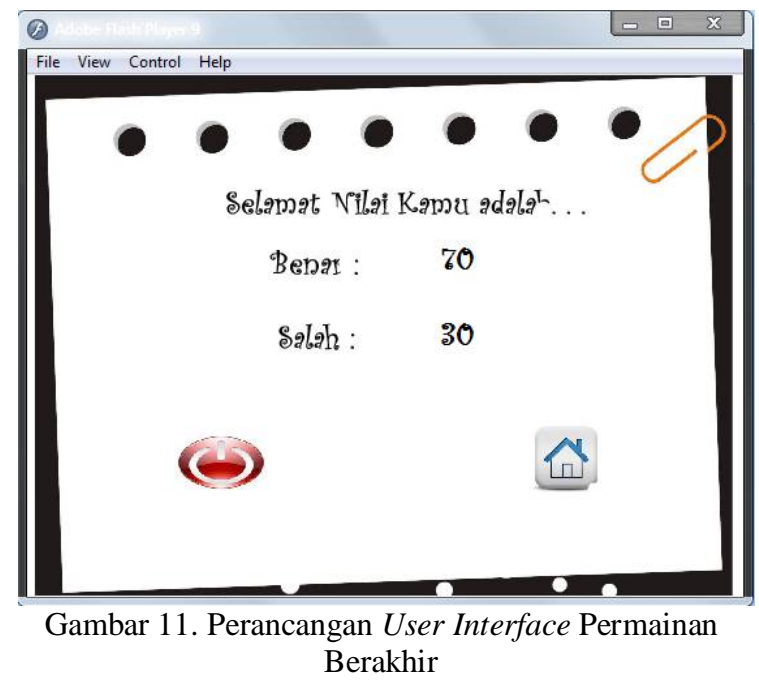

Rancangan menu permainan berakhir ini terdapat keterangan nilai dari pertanyaan-pertanyaan yang telah user jawab, dan terdapat dus tombol. Tombol keluar ini akan keluar dari aplikasi, dan tombol kembali akan terhubung ke halaman awal.

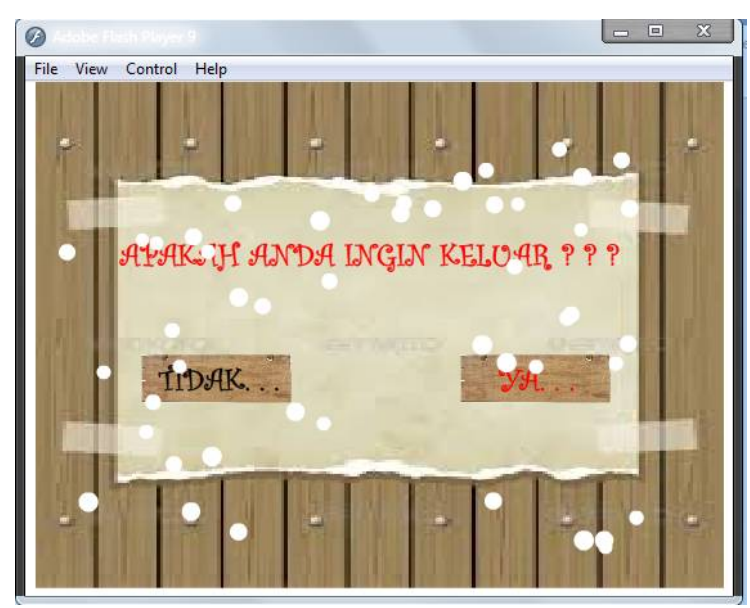

Gambar 12. Perancangan User Interface Keluar

Rancangan menu keluar ini akan muncul jika pemain mengklik tombol keluar yang berada dalam halaman menu utama. Halaman ini berisi dua tombol yaitu tombol ya dan tombol tidak. Tombol ya digunakan jika pemain ingin keluar dari aplikasi edukasi biologi. Tombol tidak digunakan jika pemain tidak ingin keluar dari aplikasi edukasi biologi.

\section{A. Pengujian Whitebox}

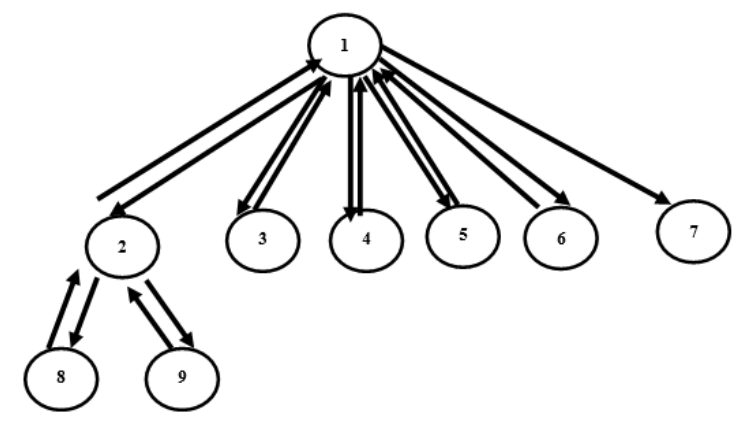

Gambar 13. Diagram Alir Aplikasi

Path yang dapat dibentuk sebagai berikut:

Path 1 : 1-2-1

Path 2 : 1-2-8-1

Path 3 : 1-2-9-1

Path 4 : 1-3-1

Path $5: 1-4-1$

Path 6 : 1-5-1

Path 7 : 1-6-1

Path 8: 1-7

Region yang dapat dibentuk sebanyak delapan (8), selanjutnya akan di uji dengan menggunakan rumus Cyclomatic Complexcity.

$$
\begin{aligned}
\mathrm{V}(\mathrm{G}) & =\mathrm{E}-\mathrm{N}+2 \\
& =15-9+2 \\
& =8
\end{aligned}
$$

Dari region yang didapat menggunakan diagram alir dan rumus menunjukan jumlah yang sama, yang artinya sistem sudah berjalan dengan benar. 
Selanjutnya akan diteruskan dengan pengujian blackbox. atau tidak. Berikut hasil pengujian setiap tombol pada tiap Scene.

\section{B. Pengujian Blackbox}

Pengujian black box akan menguji apakah tombol-tombol pada tiap Scene bekerja dengan baik

Tabel 2. Pengujian Blackbox

\begin{tabular}{|c|c|c|c|}
\hline Scene & Uraian & Hasil Yang Diharapkan & Hasil Uji \\
\hline \multirow{4}{*}{1} & $\begin{array}{l}\text { Terdiri dari } 2 \text { frame dengan animasi } \\
\text { berjalan }\end{array}$ & & \\
\hline & Frame 1 & & \\
\hline & - $\quad$ Klik tombol start & Menampilkan halaman menu tampilan & Sesuai \\
\hline & - $\quad$ Klik tombol exit & Menutup aplikasi & Sesuai \\
\hline \multirow{13}{*}{2} & $\begin{array}{l}\text { Terdiri dari } 7 \text { frame, dengan animasi } \\
\text { berjalan }\end{array}$ & & \\
\hline & Frame 1 & & \\
\hline & $\begin{array}{ll} & \begin{array}{l}\text { Klik sistem reproduksi } \\
\text { manusia }\end{array}\end{array}$ & Menampilkan halaman sistem reproduksi manusia & Sesuai \\
\hline & $\begin{array}{l}\text { Klik tombol fertilisasi dan } \\
\text { perkembangan embrio }\end{array}$ & $\begin{array}{l}\text { Menampilkan halaman fertilisasi dan perkembangan } \\
\text { embrio }\end{array}$ & Sesuai \\
\hline & $\begin{array}{ll}- & \text { Klik tombol siklus } \\
& \text { menstruasi }\end{array}$ & Menampilkan halaman siklus menstruasi & Sesuai \\
\hline & $\begin{array}{ll}- & \text { Klik tombol mengenal } \\
\text { penyakit AIDS }\end{array}$ & Menampilkan halaman mengenal penyakit AIDS & Sesuai \\
\hline & $\begin{array}{ll}\text { - } & \text { Klik tombol uji kompetensi } \\
\text { siswa }\end{array}$ & Menampilkan halaman uji kompetensi siswa & Sesuai \\
\hline & $-\quad$ Klik tombol kembali & Kembali ke menu utama & Sesuai \\
\hline & Frame 3 & & \\
\hline & $\begin{array}{ll}\text { - } & \text { Klik alat reproduksi laki - } \\
& \text { laki }\end{array}$ & $\begin{array}{l}\text { Menampilkan halaman dan keterangan alat reproduksi } \\
\text { laki - laki }\end{array}$ & Sesuai \\
\hline & - $\quad$ Klik alat reproduksi wanita & $\begin{array}{l}\text { Menampilkan halaman dan keterangan alat reproduksi } \\
\text { wanita }\end{array}$ & Sesuai \\
\hline & $-\quad$ Klik tombol kembali & Kembali ke menu pilihan & Sesuai \\
\hline & $\begin{array}{l}\text { Frame } 39,49, \text { dan } 59 \\
\text { Berisi halaman keterangan mengenai } \\
\text { bahasan masing - masing }\end{array}$ & $\begin{array}{l}\text { Frame } 39,49 \text {, dan } 59 \text { menampilkan materi mengenai } \\
\text { bahasan masing - masing }\end{array}$ & Sesuai \\
\hline \multirow{13}{*}{3} & $\begin{array}{l}\text { Terdiri dari } 11 \text { frame, dengan } \\
\text { animasi berjalan }\end{array}$ & & \\
\hline & Frame 1 & & \\
\hline & $\begin{array}{ll}\text { - } & \text { Klik tombol alat reproduksi } \\
& \text { laki - laki }\end{array}$ & Menampilkan halaman menu alat reproduksi laki - laki & Sesuai \\
\hline & $\begin{array}{l}\text { Klik tombol alat reproduksi } \\
\text { wanita }\end{array}$ & Menampilkan halaman menu alat reproduksi wanita & Sesuai \\
\hline & $-\quad$ Klik tombol kembali & Kembali ke halaman menu pilihan & Sesuai \\
\hline & Frame 4 & & \\
\hline & - $\quad$ Tampilan teori & Menampilkan teori dari sistem reproduksi laki - laki & Sesuai \\
\hline & - Klik tombol gambar & $\begin{array}{l}\text { Menampilkan halaman gambar dari organ sistem } \\
\text { reproduksi laki - laki }\end{array}$ & Sesuai \\
\hline & $-\quad$ Klik tombol kembali & Kembali ke halaman menu pilihan & Sesuai \\
\hline & Frame 13 & & \\
\hline & - $\quad$ Tampilan teori & Menampilkan teori dari sistem reproduksi wanita & Sesuai \\
\hline & - Klik tombol gambar & $\begin{array}{l}\text { Menampilkan halaman gambar dari organ sistem } \\
\text { reproduksi wanita }\end{array}$ & Sesuai \\
\hline & $-\quad$ Klik tombol kembali & Kembali ke halaman menu pilihan & Sesuai \\
\hline 4 & $\begin{array}{l}\text { Terdiri dari } 2 \text { frame, dengan animasi } \\
\text { berjalan }\end{array}$ & & \\
\hline
\end{tabular}




\begin{tabular}{|c|c|c|c|}
\hline Scene & Uraian & Hasil Yang Diharapkan & Hasil Uji \\
\hline & Frame 39 & & \\
\hline & - $\quad$ Tampilan teori & $\begin{array}{l}\text { Menampilkan teori fertilisasi dan perkembangan } \\
\text { embrio }\end{array}$ & Sesuai \\
\hline & - $\quad$ Klik tombol lanjutan & Menampilkan halaman selanjutnya & Sesuai \\
\hline & - $\quad$ Klik tombol kembali & Kembali ke halaman menu pilihan & Sesuai \\
\hline & Frame 40 & & \\
\hline & - Klik gambar & $\begin{array}{l}\text { Menampilkan gambar mengenai fertilisasi } \\
\text { perkembangan embrio }\end{array}$ & Sesuai \\
\hline & - $\quad$ Klik tombol lanjut & Menampilkan halaman selanjutnya & Sesuai \\
\hline & - $\quad$ Klik tombol kembali & $\begin{array}{l}\text { Kembali ke halaman menu fertilisasi perkembangan } \\
\text { embrio }\end{array}$ & Sesuai \\
\hline \multirow{9}{*}{5} & $\begin{array}{l}\text { Terdiri dari } 2 \text { frame, dengan animasi } \\
\text { berjalan }\end{array}$ & & \\
\hline & Frame 49 & & \\
\hline & - $\quad$ Tampilan teori & Menampilkan teori siklus menstruasi & Sesuai \\
\hline & - $\quad$ Klik tombol lanjut & Menampilkan halaman selanjutnya & Sesuai \\
\hline & - $\quad$ Klik tombol kembali & Kembali ke halaman menu pilihan & Sesuai \\
\hline & Frame 50 & & \\
\hline & - $\quad$ Klik gambar & Menampilkan gambar mengenai siklus menstruasi & Sesuai \\
\hline & - $\quad$ Klik tombol lanjut & Menampilkan halaman selanjutnya & Sesuai \\
\hline & - $\quad$ Klik tombol kembali & Kembali ke halaman menu siklus menstruasi & Sesuai \\
\hline \multirow{9}{*}{6} & $\begin{array}{l}\text { Terdiri dari } 2 \text { frame, dengan animasi } \\
\text { berjalan }\end{array}$ & & \\
\hline & Frame 59 & & \\
\hline & - $\quad$ Tampilan teori & Menampilkan teori mengenal penyakit AIDS & Sesuai \\
\hline & - $\quad$ Klik tombol lanjut & Menampilkan halaman selanjutnya & Sesuai \\
\hline & - $\quad$ Klik tombol kembali & Kembali ke halaman menu pilihan & Sesuai \\
\hline & Frame 60 & & \\
\hline & - $\quad$ Klik gambar & $\begin{array}{l}\text { Menampilkan gambar mengenai pengenalan penyakit } \\
\text { AIDS }\end{array}$ & Sesuai \\
\hline & - $\quad$ Klik tombol lanjut & Menampilkan halaman selanjutnya & Sesuai \\
\hline & $-\quad$ Klik tombol kembali & Kembali ke halaman menu mengenal penyakit AIDS & Sesuai \\
\hline \multirow{15}{*}{7} & $\begin{array}{l}\text { Terdiri dari } 2 \text { frame, dengan animasi } \\
\text { berjalan }\end{array}$ & & \\
\hline & Frame 23 & & \\
\hline & - $\quad$ Aturan permainan & Menampilkan aturan permainan & Sesuai \\
\hline & - $\quad$ Klik tombol mulai & Menampilkan halaman soal uji kompetensi & Sesuai \\
\hline & - $\quad$ Klik tombol kembali & Kembali ke menu utama & Sesuai \\
\hline & Frame $24-33$ & & \\
\hline & - $\quad$ Tampilan soal & Menampilkan soal uji kompetensi & Sesuai \\
\hline & - $\quad$ Klik tombol pilihan A & Jawaban pilihan A & Sesuai \\
\hline & - $\quad$ Klik tombol pilihan B & Jawaban pilihan B & Sesuai \\
\hline & - $\quad$ Klik tombol pilihan $\mathrm{C}$ & Jawaban pilihan $\mathrm{C}$ & Sesuai \\
\hline & - $\quad$ Klik tombol pilihan D & Jawaban pilihan D & Sesuai \\
\hline & Frame 34 & & \\
\hline & $\begin{array}{l}\text { - } \quad \begin{array}{l}\text { Halaman permainan } \\
\text { berakhir }\end{array}\end{array}$ & Menampillkan halaman nilai pemain & Sesuai \\
\hline & $\begin{array}{ll} & \text { Klik tombol keluar } \\
\end{array}$ & Keluar dari aplikasi & Sesuai \\
\hline & - $\quad$ Klik tombol halaman utama & Kembali ke halaman utama & Sesuai \\
\hline
\end{tabular}

C. Hasil Pengolahan Kuisioner

Tabel IV. Tabel Hasil Kuisioner Secara Keseluruhan

\begin{tabular}{|c|c|c|c|c|c|c|c|c|c|}
\hline \multirow{2}{*}{ No. } & \multicolumn{2}{|c|}{ Pertanyaan } & Ya & $\%$ & Tidak & $\%$ & Bagus & $\%$ & \multicolumn{2}{c|}{$\begin{array}{c}\text { Kurang } \\
\text { Bagus }\end{array}$} & \begin{tabular}{c}
$\%$ \\
\cline { 4 - 8 }
\end{tabular} \\
\hline & $\begin{array}{l}\text { Menurut adik- adik apakah } \\
\text { aplikasi ini sangat mudah } \\
\text { digunakan? }\end{array}$ & 20 & 100 & 0 & 0 & 0 & 0 & 0 & 0 \\
\hline
\end{tabular}


Jurnal SISFOKOM, Volume 04, Nomor 02, September 2015

\begin{tabular}{|c|c|c|c|c|c|c|c|c|c|}
\hline \multirow[b]{2}{*}{ No. } & \multirow[b]{2}{*}{ Pertanyaan } & \multicolumn{8}{|c|}{ Jawaban } \\
\hline & & Ya & $\%$ & Tidak & $\%$ & Bagus & $\%$ & $\begin{array}{c}\text { Kurang } \\
\text { Bagus }\end{array}$ & $\%$ \\
\hline 2. & $\begin{array}{l}\text { Apakah aplikasi ini dapat } \\
\text { membantu adik-adik dalam } \\
\text { mengenal sistem reproduksi } \\
\text { manusia? }\end{array}$ & 20 & 100 & 0 & 0 & 0 & 0 & 0 & 0 \\
\hline 3. & $\begin{array}{l}\text { Apakah adik-adik menyukai } \\
\text { pelajaran biologi? }\end{array}$ & 20 & 100 & 0 & 0 & 0 & 0 & 0 & 0 \\
\hline 4. & $\begin{array}{l}\text { Apakah setelah mencoba } \\
\text { aplikasi ini adik-adik tertarik } \\
\text { dengan pelajaran biologi? }\end{array}$ & 20 & 100 & 0 & 0 & 0 & 0 & 0 & 0 \\
\hline 5. & $\begin{array}{l}\text { Apakah aplikasi ini } \\
\text { merangsang adik-adik lebih } \\
\text { kreatif dalam belajar biologi? }\end{array}$ & 20 & 100 & 0 & 0 & 0 & 0 & 0 & 0 \\
\hline 6. & $\begin{array}{l}\text { Menurut adik-adik apakah } \\
\text { aplikasi ini menarik untuk } \\
\text { dipelajari? }\end{array}$ & 20 & 100 & 0 & 0 & 0 & 0 & 0 & 0 \\
\hline 7. & $\begin{array}{l}\text { Menurut adik-adik apakah } \\
\text { materi didalam aplikasi ini } \\
\text { sulit dimengerti? }\end{array}$ & 0 & 0 & 20 & 100 & 0 & 0 & 0 & 0 \\
\hline 8. & $\begin{array}{l}\text { Menurut adik-adik apakah } \\
\text { soal - soal yang ada di uji } \\
\text { kompetensi sulit untuk } \\
\text { dijawab? }\end{array}$ & 2 & 10 & 18 & 90 & 0 & 0 & 0 & 0 \\
\hline 9. & $\begin{array}{l}\text { Apakah edukasi yang } \\
\text { ditampilkan dapat menambah } \\
\text { wawasan anda? }\end{array}$ & 20 & 100 & 0 & 0 & 0 & 0 & 0 & 0 \\
\hline 10. & $\begin{array}{l}\text { Menurut adik-adik, apa kesan } \\
\text { yang adik-adik dapatkan } \\
\text { setelah mencoba aplikasi ini? }\end{array}$ & 0 & 0 & 0 & 0 & 20 & 100 & 0 & 0 \\
\hline & Total & 142 & 71 & 38 & 19 & 20 & 10 & 0 & 0 \\
\hline
\end{tabular}

\section{Diagram Pengolahan Kuisioner}

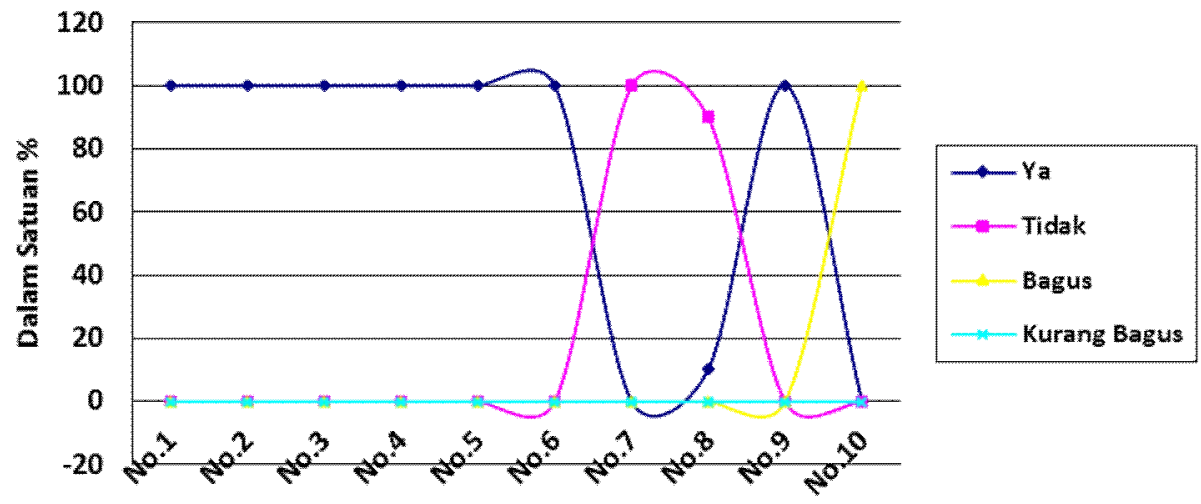

Gambar 14. Diagram Hasil Kuisioner Secara Keseluruhan

Ditahap ini penulis melakukan survey mengenai program aplikasi edukasi biologi sistem reproduksi manusia yang telah dibuat dan dilakukan oleh dua puluh responden. Survey ini akan dilakukan dengan cara membagikan kuisioner yang berisi sepuluh pertanyaan seputar pengetahuan responden tentang permainan tembak binatang serta penilaian mereka mengenai program aplikasinya. Tabel dan gambar diatas adalah uraian dan penjelasan dari hasil pengolahan data kuisioner permainan edukasi tembak binatang berdasarkan jawaban-jawaban yang telah diberikan oleh para responden. Data akan disajikan dalam bentuk tabel dan diagram lingkaran.

A. Kesimpulan

\section{PENUTUP}

Setelah penulis mencoba dan menjalankan program aplikasi edukasi biologi tentang sistem 
reproduksi manusia yang telah dibuat, maka penulis mengambil beberapa kesimpulan di antaranya sebagai berikut:

- Aplikasi edukasi biologi ini dibuat dengan menggunakan Adobe Flash CS3.

- Aplikasi edukasi ini selain menampilkan materi pelajaran juga menampilkan uji kompetensi siswa.

- Aplikasi edukasi biologi ini ditujukan untuk anakanak dengan usia 14 tahun atau siswa SMP kelas IX

B. Saran

Adapun saran yang dapat memperbaiki aplikasi edukasi biologi ini agar nantinya dapat menjadi lebih baik lagi yaitu sebagai berikut:

- Agar lebih menarik, aplikasi edukasi biologi harus diberikan animasi yang lebih menarik.

- Memberikan animasi yang lebih menarik dan interaktif.

- Penambahan efek suara yang lebih menarik lagi dalam aplikasi ini agar pemain bisa lebih nyaman dalam menjalankan aplikasi ini.

- Kelebihan dan kekurangan dari aplikasi edukasi biologi ini dapat dikembangkan dan di perbaiki lagi, sehingga nantinya aplikasi edukasi biologi yang akan datang akan menjadi lebih menarik dan lebih baik dari sebelumnya.

\section{DAFTAR PUSTAKA}

[1] Feri Sulianta, 2010, Interaksi Manusia dan Komputer, Jakarta: IT Ergonomik, PT Elex Media Komputindo.

[2] Hanif Al Fatta, 2008, Analisis \& Perancangan Sistem Informasi untuk Keunggulan Bersaing Perusahaan \& Organisasi Modern, Yogyakarta: Andi.

[3] Hendrayudi, 2009, VB 2008 untuk Berbagai Keperluan Pemrograman, Jakarta: Elex Media Komputindo.

[4] Inap Santoso, 2010, Interaksi Manusia dan Komputer, Yogyakarta: Andi Publisher.

[5] Kusrini, M.Kom, Koniyo Andri, 2007, Tuntunan Praktis Membangun Sistem Informasi Akuntansi dengan Visual Basic \& Microsoft SQL Server, Yogyakarta: Andi.

[6] Madcoms, 2009, Panduan Lengkap Editing Video dengan Adobe Premiere Pro CS4, Yogyakarta: Andi. 
Jurnal SISFOKOM, Volume 04, Nomor 02, September 2015 